\title{
NURSE PRESCRIBING. THE KNOWLEDGE OF NURSING AND MIDWIFERY STUDENTS REGARDING NEW PROFESSIONAL COMPETENCES. POLAND-WIDE MULTICENTER STUDY
}

\author{
ALEKSANDER ZARZEKA ${ }^{1 *}$, MARIUSZ PANCZYK ${ }^{1}$, JAROSŁAWA BELOWSKA', \\ LUCYNA IWANOW ${ }^{1}$, ILONA CIEŚLAK ${ }^{1}$, NICOLE MAZUR ${ }^{2}$, BERTA PAZ LOURIDO ${ }^{3}$ \\ and JOANNA GOTLIB'
}

${ }^{1}$ Department of Teaching and Outcomes of Education, Faculty of Health Science, The Medical University of Warsaw, Poland

${ }^{2}$ Department of Clinical Nursing, Faculty of Health Science, The Medical University of Warsaw, Poland ${ }^{3}$ Department of Nursing and Physiotherapy, The University of Balearic Islands, Spain

\begin{abstract}
Since 1 January 2016 certain groups of nurses and midwives (N\&Ms) have been entitled to administer certain medicines to patients and issue perceptions for it (independent nurse prescribing - INP), issue prescriptions upon physician's order (supplementary nurse prescribing - SNP) and to refer patients to determined diagnostic tests. Students' knowledge on the possibility and principles of nurse prescribing seems to be important. To evaluate the knowledge of $1^{\text {st }}$ year students of Bachelor's studies in nursing and midwifery on the possibility and principles of prescribing authorities of N\&Ms in Poland. $23381^{\text {st }}$ year students of Bachelor's nursing (1941) and midwifery (398) studies from 26 state higher vocational schools of universities. Own questionnaire assessed in the pilot study; the internal reliability of measurement on the knowledge rating scale was estimated by calculating Cronbach's alpha reliability coefficient. Group of $11 \%$ to $64 \%$ (depending on a question) gave correct answers. $14 \%$ knew criteria which N\&Ms are required to meet in order to refer patients to diagnostic tests. Almost $2 / 3$ of the interviewees also knew where to find the list of active substances allowed in medicines independently prescribed by N\&Ms. The internal reliability of the knowledge rating scale was 0.389 . The knowledge of students regarding N\&Ms' prescribing powers is superficial, but most of the respondents knew the crucial issues. It is necessary to correctly determine education standards and to focus on their implementation tools so that those concerned could acquire desired competencies during studies.
\end{abstract}

Keywords: drug prescription; legislation, drug; legislation, nursing; schools, nursing

Since 1 January 2016 certain groups of nurses and midwives (N\&Ms) have been entitled to administer certain medicines to patients and issue perceptions for it (independent nurse prescribing - INP), issue prescriptions upon physician's order (supplementary nurse prescribing - SNP) and to refer patients to determined diagnostic tests. The new competencies stem from an amendment to the Act on nurse and midwife professions enacted on 22 July 2014 (1). The scope of N\&Ms' powers depends on the scope of training they received.

For INP, N\&Ms are required to hold a Master's degree in nursing/midwifery or a Specialist's degree in nursing and to have a specialist course in independent and supplementary prescribing completed. Whereas for SNP, N\&Ms will be required to hold a Bachelor's degree in nursing/midwifery or a
Specialist's degree in nursing and to have a specialist course in supplementary prescribing completed. No special courses will be required when curricula of such courses form part of a university curriculum. The first year of students to acquire prescribing powers began nursing/midwifery studies in 2016.

It should be highlighted that INP of certain medicines (the list of active substances which are allowed in such medicines is set forth in the Regulation of the Minister of Health (2)) will be a right, rather than a duty, of N\&Ms. SNP, in turn, will be obligatory as any other physician's order.

N\&Ms will be entitled to independent and supplementary prescribing of reimbursable medicines, including medicines for those who enjoy special entitlements, for instance, disabled veterans or honorary blood donors (3). In such a case, N\&Ms are

$\bar{*}$ Corresponding author: e-mail: aleksander.zarzeka@wum.edu.pl 
obliged to point out a rate of patient's share in financing, but only if a given medicine has at least two different rates of patient's share in financing assigned (e.g., 30\% for indication $\mathrm{X}$ and $50 \%$ for indication $\mathrm{Y}$ ). If a given medicine has only one rate of patient's share in financing assigned, the rate of the share does not have to be placed on a prescription (4). It should also be mentioned that only a Primary Care Nurse will be entitled to prescribe free of charge medicines for people who are over 75 years old.

Moreover, the amendment empowers N\&Ms to independently refer patients to diagnostic tests.
This power will be vested in N\&Ms who hold a Bachelor's degree in nursing/midwifery or a Specialist's degree in nursing. The list of such tests is also set forth in the Regulation of the Minister of Health (2).

Nursing and midwifery students who begin their studies in the academic year 2016/2017 will acquire the majority of the mentioned powers upon graduating and claiming their right to exercise the profession. Since the research covers only $1^{\text {st }}$ year students, their knowledge has been assessed before the pharmacology training. Content and quality of such pharmacology course can be an important fac-

Table 1. Structure of the study group.

\begin{tabular}{|c|c|c|c|c|}
\hline \multirow{2}{*}{ Center } & \multicolumn{2}{|c|}{ Study participants } & \multirow{2}{*}{$\begin{array}{c}\text { Number of all } \\
\text { nursing or } \\
\text { midwifery students }\end{array}$} & \multirow{2}{*}{$\begin{array}{l}\text { Response } \\
\text { rate }\end{array}$} \\
\hline & Number & $\%$ & & \\
\hline Medical University of Silesia in Katowice & 258 & 11 & 317 & $81 \%$ \\
\hline Medical University of Warsaw & 189 & 8 & 368 & $51 \%$ \\
\hline Medical University of Łódź & 184 & 7.8 & 278 & $66 \%$ \\
\hline Medical University of Wrocław & 150 & 6.4 & 154 & $97 \%$ \\
\hline Pomeranian Medical University in Szczecin & 140 & 5.9 & 187 & $75 \%$ \\
\hline Medical University of Lublin & 124 & 5.3 & 230 & $54 \%$ \\
\hline Jan Kochanowski University in Kielce & 117 & 5 & 141 & $83 \%$ \\
\hline Medical University of Białystok & 108 & 4.6 & 116 & $93 \%$ \\
\hline State Higher Vocational School in Tarnów & 105 & 4.5 & 115 & $91 \%$ \\
\hline State Higher Vocational School in Płock & 104 & 4,4 & 121 & $86 \%$ \\
\hline State Higher Vocational School in Krosno & 93 & 4 & 122 & $76 \%$ \\
\hline University of Rzeszów & 90 & 3.8 & 139 & $65 \%$ \\
\hline State Medical Higher Vocational School in Opole & 85 & 3.6 & 152 & $56 \%$ \\
\hline State Higher Vocational School in Kalisz & 70 & 3 & 104 & $67 \%$ \\
\hline State Higher Vocational School in Nowy Sącz & 65 & 2.8 & 93 & $70 \%$ \\
\hline State Higher Vocational School in Ciechanów & 61 & 2.6 & 85 & $72 \%$ \\
\hline $\begin{array}{l}\text { State Higher Vocational School of Podhale } \\
\text { in Nowy Targ }\end{array}$ & 54 & 2.3 & 79 & $68 \%$ \\
\hline State Higher Vocational School in Biała Podlaska & 51 & 2.2 & 83 & $61 \%$ \\
\hline State Higher Vocational School in Leszno & 51 & 2.2 & 70 & $73 \%$ \\
\hline State Higher Vocational School in Tarnobrzeg & 47 & 2 & 94 & $50 \%$ \\
\hline $\begin{array}{l}\text { State College of Computer Science and Business } \\
\text { Administration in Łomża }\end{array}$ & 39 & 1.7 & 60 & $65 \%$ \\
\hline State Higher Vocational School in Oświęcim & 39 & 1.7 & 64 & $61 \%$ \\
\hline State Higher Vocational School in Suwałki & 36 & 1.5 & 41 & $88 \%$ \\
\hline Karkonosze State Higher School in Jelenia Góra & 35 & 1.5 & 47 & $74 \%$ \\
\hline State Higher Vocational School in Chełm & 30 & 1.3 & 70 & $43 \%$ \\
\hline State Higher Vocational School in Piła & 28 & 1.2 & 48 & $58 \%$ \\
\hline TOTAL & $2353^{*}$ & 100 & 3378 & $70 \%$ \\
\hline
\end{tabular}

*25 questionnaires with more than one answer marked had been excluded 
tor of students' knowledge in the moment of graduation $(5,6)$. Hence their knowledge regarding the possibility and principles nurse prescribing seems to be a vital starting point for further studies in the subject area.

\section{Aim of study \\ The aim of the study was to evaluate the knowledge of $1^{\text {st }}$ year students of Bachelor's studies in nursing and midwifery on the possibility and principles of independent prescribing, supplemen- tary prescribing and referring patients to diagnostic tests by certain groups of nurses and midwives in Poland.}

\section{MATERIAL AND METHODS}

\section{Study design}

This study is yet another stage of a project which analyses the knowledge and attitudes of different groups of stakeholders about expanding nurses' and midwives' competences in the field of INP, SNP and referring patients to determined diagnostic tests. It was preceded by a pilot study carried out in a group of students of the Medical University of Warsaw (7) and by the assessment of validity and reliability of a questionnaire (8).

As a result of preliminary studies, necessary corrections to the questionnaire were made and the Poland-wide research project was initiated in a group of $1^{\text {st }}$ year students of Bachelor's studies in nursery and midwifery. The study will be repeated in 2 years in the same group of people - on a day prior to their graduation in Bachelor's studies and acquisition of part of the professional qualifications.

\section{Selection of study group}

The author's objective was to conduct a study in a representative and as broad as possible group of $1^{\text {st }}$ year students of Bachelor's studies in nursing and midwifery in Poland. To achieve that, invitations to participate in the study were sent out to 38 public education centers, including all 23 state higher vocational schools and all 14 universities which conduct training in at least one of these fields.

26 centers provided positive answers expressing their willingness to undertake the cooperation, and ultimately the students of these centers took part in the study. Thus the response rate at the level of the engaged centers was $68 \%$. Every center established the local coordinator who passed paper questionnaires to the students. Fulfilled were sent to the national coordinator of the study and analyzed. The list of the centers, together with the number of students who took part in the study in a given center, is presented in Table 1.

It should be stated that due to such a selection of study group, the study group meets the criteria of representativeness for a group of $1^{\text {st }}$ year students of Bachelor's studies in nursing and midwifery at state universities and higher vocational schools in Poland.

\section{Questionnaire}

The study was conducted using a questionnaire which had been prepared by the authors and whose validity and reliability had been assessed in the pilot study (8). On the basis of the pilot study, the questionnaire was adjusted to the needs of this study.

The questionnaire focused on the knowledge of the respondents on the new professional competencies of nurses and midwives in the field of independent nurse prescribing, supplementary nurse prescribing and referring patients to diagnostic tests and on the manner of exercising these competencies. It consisted of 10 questions, with four answer choices each of which only one answer was correct. In every question a respondent could choose an "I don't know" answer option.

\section{Statistical analysis}

The obtained results were evaluated by determining structural indicators. Moreover, the internal reliability of measurement on the knowledge rating scale was estimated by calculating Cronbach's alpha reliability coefficient. All test positions were also evaluated by determining parameters of differentiating capacity for correct option and proper functioning of distractions (incorrect options). Differentiating capacity (discrimination index), which assesses the relation between test positions and the overall test result, should be of at least 0.20 (9). Distractions with a structural indicator above 0.05 were deemed functional (10). The assessment of distractions' functioning took into account "I don't know" option. All calculations were made using STATISTICA statistical package, version 13.1 (StatSoft. Inc.) under the license of the Medical University of Warsaw.

\section{Bioethics committee}

This study is not subject to an opinion of the Bioethics Committee, since pursuant to a communication placed on the website of the Bioethics Committee of the Medical University of Warsaw "the Committee does not issue opinions on questionnaire-based studies, retrospective studies and non-invasive research" (11). 
Table 2. Knowledge of nursing and midwifery students.

\begin{tabular}{|c|c|c|c|}
\hline Question & Answer & $\mathrm{n}$ & $\%$ \\
\hline \multirow{5}{*}{$\begin{array}{l}\text { 1. Which act sets forth nurses' and } \\
\text { midwives' professional } \\
\text { competences regarding independent } \\
\text { prescribing of particular medicines } \\
\text { and supplementary prescribing? }\end{array}$} & $\begin{array}{l}\text { In the Act of } 12 \text { May } 2011 \text { on reimbursement } \\
\text { of medical products, foodstuffs intended for } \\
\text { particular nutritional uses, and medical devices }\end{array}$ & 296 & 12.7 \\
\hline & $\begin{array}{l}\text { In the Act of } 15 \text { July } 2011 \text { on nurse and } \\
\text { midwife professions* }\end{array}$ & 1071 & 45.8 \\
\hline & $\begin{array}{l}\text { In the Act of } 1 \text { July } 2011 \text { on nurses and } \\
\text { midwives' professional association }\end{array}$ & 145 & 6.2 \\
\hline & I don't know & 812 & 34.7 \\
\hline & No answer & 14 & 0.6 \\
\hline \multirow{5}{*}{$\begin{array}{l}\text { 2. When will particular groups of } \\
\text { nurses and midwives in Poland be } \\
\text { entitled to independent prescribing } \\
\text { of particular medicines and to } \\
\text { supplementary prescribing? }\end{array}$} & From 1 January 2017 & 238 & 10.1 \\
\hline & From 1 July 2016 & 371 & 15.9 \\
\hline & From 1 January 2016* & 1355 & 58 \\
\hline & I don't know & 366 & 15.7 \\
\hline & No answer & 8 & 0.3 \\
\hline \multirow{5}{*}{$\begin{array}{l}\text { 3.Will independent prescribing of } \\
\text { particular medicines be a duty of an } \\
\text { entitled nurse or midwife? }\end{array}$} & Yes & 883 & 37.8 \\
\hline & No* & 595 & 25.4 \\
\hline & It depends on a form of employment & 558 & 23.9 \\
\hline & I don't know & 295 & 12.6 \\
\hline & No answer & 7 & 0.3 \\
\hline \multirow{5}{*}{$\begin{array}{l}\text { 4. Please indicate the criteria which } \\
\text { a nurse or midwife will have to } \\
\text { meet in order to be entitled to } \\
\text { independent prescribing of } \\
\text { particular medicines and to issue } \\
\text { prescriptions for it. }\end{array}$} & $\begin{array}{c}\text { Bachelor's degree in nursing/midwifery or a } \\
\text { Specialist's degree in nursing and a specialist } \\
\text { course in independent and supplementary } \\
\text { prescribing completed }\end{array}$ & 717 & 30.6 \\
\hline & $\begin{array}{l}\text { Master's degree in nursing/midwifery or a } \\
\text { Specialist's degree in nursing }\end{array}$ & 224 & 9.6 \\
\hline & $\begin{array}{l}\text { Master's degree in nursing/midwifery or a } \\
\text { Specialist's degree in nursing and a specialist } \\
\text { course in independent and supplementary } \\
\text { prescribing completed* }\end{array}$ & 1181 & 50.6 \\
\hline & I don't know & 191 & 8.2 \\
\hline & No answer & 25 & 1 \\
\hline \multirow{5}{*}{$\begin{array}{l}\text { 5. Please indicate the criteria which } \\
\text { a nurse or midwife will have to } \\
\text { meet in order to be entitled to } \\
\text { supplementary prescribing within } \\
\text { the scope of a treatment ordered } \\
\text { by a physician }\end{array}$} & $\begin{array}{l}\text { Bachelor's degree in nursing/midwifery or a } \\
\text { Specialist's degree in nursing }\end{array}$ & 271 & 11.6 \\
\hline & $\begin{array}{c}\text { Bachelor's degree in nursing/midwifery or a } \\
\text { Specialist's degree in nursing and a specialist } \\
\text { course in supplementary } \\
\text { prescribing completed* }\end{array}$ & 913 & 39 \\
\hline & $\begin{array}{c}\text { Master's degree in nursing/midwifery and a } \\
\text { specialist course in supplementary } \\
\text { prescribing completed }\end{array}$ & 897 & 38.4 \\
\hline & I don't know & 233 & 10 \\
\hline & No answer & 24 & 1 \\
\hline \multirow{5}{*}{$\begin{array}{l}\text { 6. Please indicate the criteria which } \\
\text { a nurse or midwife will have to } \\
\text { meet in order to independently refer } \\
\text { patients to determined } \\
\text { diagnostic tests }\end{array}$} & $\begin{array}{l}\text { Bachelor's degree in nursing/midwifery or a } \\
\text { Specialist's degree in nursing and a specialist } \\
\text { course in making referrals completed }\end{array}$ & 828 & 35.4 \\
\hline & $\begin{array}{l}\text { Bachelor's degree in nursing/midwifery or a } \\
\text { Specialist's degree in nursing* }\end{array}$ & 246 & 10.6 \\
\hline & $\begin{array}{l}\text { Master's degree in nursing/midwifery or a } \\
\text { Specialist's degree in nursing }\end{array}$ & 808 & 34.6 \\
\hline & I don't know & 448 & 19.1 \\
\hline & No answer & 8 & 0.3 \\
\hline
\end{tabular}


Table 2. Continued.

\begin{tabular}{|c|c|c|c|}
\hline Question & Answer & $\mathrm{n}$ & $\%$ \\
\hline \multirow{6}{*}{$\begin{array}{l}\text { 7. Which tests will be covered by } \\
\text { nurses' and midwives' competence } \\
\text { to independently make referrals in } \\
\text { the process of diagnosis }\end{array}$} & $\begin{array}{l}\text { Any tests, except for diagnostic methods which } \\
\text { constitute an increased risk for the patient }\end{array}$ & 347 & 14.8 \\
\hline & $\begin{array}{l}\text { Only tests within the scope of laboratory } \\
\text { diagnosis }\end{array}$ & 299 & 12.8 \\
\hline & $\begin{array}{l}\text { Only tests specified in the Regulation of } \\
\text { the Minister of Health* }\end{array}$ & 1120 & 48 \\
\hline & I don't know & 564 & 24.1 \\
\hline & No answer & 8 & 0.3 \\
\hline & Yes, always & 713 & 30.5 \\
\hline \multirow{4}{*}{$\begin{array}{l}\text { 8. Will a nurse/midwife be } \\
\text { obliged to point out the rate } \\
\text { of patient's share in financing } \\
\text { while prescribing a reimbursable } \\
\text { medicinal product? }\end{array}$} & $\begin{array}{l}\text { Only if a given product has at least two rates of } \\
\text { patient's share in financing assigned* }\end{array}$ & 321 & 13.7 \\
\hline & $\begin{array}{l}\text { No, the rate of patient's share in financing is } \\
\text { specified by a pharmacist who dispenses a medicine }\end{array}$ & 411 & 17.6 \\
\hline & I don't know & 882 & 37.7 \\
\hline & No answer & 11 & 0.5 \\
\hline \multirow{5}{*}{$\begin{array}{l}\text { 9. Will nurses and midwives be } \\
\text { entitled to prescribe free of charge } \\
\text { medicines for those who enjoy special } \\
\text { entitlements (disabled war and } \\
\text { military veterans, distinguished } \\
\text { honorary blood donors)? }\end{array}$} & Yes* & 612 & 26.2 \\
\hline & $\begin{array}{l}\text { Yes, but only in the case of prescriptions } \\
\text { issued by physician's order }\end{array}$ & 788 & 33.7 \\
\hline & No & 113 & 4.8 \\
\hline & I don't know & 815 & 34.9 \\
\hline & No answer & 10 & 0.4 \\
\hline \multirow{5}{*}{$\begin{array}{l}\text { 10. The list of active substances } \\
\text { allowed in medicines independently } \\
\text { prescribed by nurses and } \\
\text { midwives is set forth in: }\end{array}$} & the Regulation of the Minister of Health* & 1498 & 64.1 \\
\hline & $\begin{array}{l}\text { the Order of the President of the } \\
\text { National Health Fund }\end{array}$ & 196 & 8.4 \\
\hline & the Polish or European Pharmacopoeia & 124 & 5.3 \\
\hline & I don't know & 514 & 22 \\
\hline & No answer & 6 & 0.2 \\
\hline
\end{tabular}

*correct answer

\section{RESULTS}

\section{Study group}

$23381^{\text {st }}$ year students of Bachelor's studies participated in the study, including 398 (17\%) midwifery students and 1941 (83\%) nursing students. $7 \%$ of the study group were men and $93 \%$ women. $44 \%$ of the respondents stated as their place of residence a village, $29 \%$ a town with up to 100 thousand inhabitants, $16 \%$ a city with $100-500$ thousand inhabitants. The interviewees' average age was 21.4 years and the median age was 20 years (min. 18, $\max .53, \mathrm{SD}=3.49, \mathrm{CV}=16.3 \%)$.
In the study group, $40 \%$ reported that they had already participated in some form of training in the field of medical law. When it comes to additional education, $7 \%$ graduated in other studies and 13\% still attend classes in another field.

From the total number of 2353 questionnaires which authors received from local coordinators, 25 were excluded due to the fact, that more than one answer was marked. Comparing with the total number of enrolled $1^{\text {st }}$ year nursing and midwifery students (3378), the overall response rate was equal to $70 \%$. Detailed information regarding the distribution of respondents with respect to the cen- 
ters and individual response rates have been provided in Table 1.

\section{Students' knowledge}

Correct answers to questions on the new advanced competencies of nurses and midwives (depending on a question) were given by a group of $11 \%$ to $64 \%$ of the respondents. The fewest correct answers were given to questions on placing the rate of patient's share in financing on a prescription (11\%) and on the criteria which N\&Ms will be required to meet in order to independently refer patients to diagnostic tests $(14 \%)$. One in four of the interviewees is aware that independent prescribing is a right, not a duty, of N\&Ms qualified in this regard.

Around half of the respondents knew which legal act was amended, when the amendment entered into force, and what criteria N\&Ms would have to meet in order to exercise prescribing powers. Almost $2 / 3$ of the interviewees also knew where to find the list of active substances allowed in medicines independently prescribed by N\&Ms. Detailed results, depicting the answers of the respondents to particular questions, are presented in Table 2.

The internal reliability of the knowledge rating scale estimated using standardized Cronbach's alpha amounted to 0.389 . When it comes to differentiating capacity, only in the case of question number 6 (Please indicate the criteria which a nurse or midwife will have to meet in order to independently refer patients to determined diagnostic tests) a sufficient discriminatory capacity was not obtained (correlation $<0.20)$. For four questions, estimated differentiating capacity was high or very high (correlation $>$

Table 3. Value of differentiating capacity for questions forming knowledge rating scale.

\begin{tabular}{|c|c|}
\hline Question numer & Differentiating capacity \\
\hline question 1 & 0.52 \\
\hline question 2 & 0.48 \\
\hline question 3 & 0.35 \\
\hline question 4 & 0.38 \\
\hline question 5 & 0.34 \\
\hline question 6 & $0.17 *$ \\
\hline question 7 & 0.46 \\
\hline question 8 & 0.28 \\
\hline question 9 & 0.32 \\
\hline question 10 & 0.53 \\
\hline
\end{tabular}

*value beneath expected threshold $(0.20)$
4.00). A detailed list of results of the analysis of differentiating capacity of particular questions is presented in Table 3.

The results of analysis of functioning of particular distractions (incorrect options) indicate that only in the case of question 9 (Will nurses and midwives be entitled to prescribe free of charge medicines for those who enjoy special entitlements (disabled war and military veterans, distinguished honorary blood donors)?) a low structural indicator was noted for one of options $(<0.05)$. For the other questions $100 \%$ functionality of all options was demonstrated (Table 4).

\section{DISCUSSION}

Nurses' and midwives' powers to independent prescribing and supplementary prescribing have been in force since the beginning of 2016. Also since that time specialist courses have been organized which enable N\&Ms to exercise their powers, and those concerned have begun to exercise their competences.

It should be noted that nursing and midwifery graduates who begin their studies in the academic year 2016/2017 will be allowed to exercise their new professional competences without any additional courses. For that reason, it was necessary to thoroughly study the knowledge of students of these fields on the possibility and principles of N\&Ms' independent prescribing and supplementary prescribing.

This work is the first multicenter and representative study of the knowledge of students who begin Bachelor's studies in nursing and midwifery on the subject matter in question. Therefore, the study's results might be a valuable material for decisionmakers of the Polish health policy and for the nursing, midwifery and medical communities.

The study's results indicate that students' level of knowledge on M\&Ns' independent and supplementary prescribing powers is relatively low. On average less than half of the students were able to choose correct answers to the questions posed. At the very beginning of the discussion, however, it should be stressed that the study covered only students who begin their studies, hence the obtained results are merely a starting point. The results cannot form the basis for the assessment of students' competences acquired in the course of studies or of effectiveness of academic education in this regard. Almost half the respondents were aware which legal act contains regulations on N\&Ms prescribing. Also around half the interviewees knew what criteria 
nurses and midwives have to meet in order to begin to exercise the new professional competencies. Two-thirds of the respondents, in turn, knew where to look up the list of medicines which can be independently prescribed by N\&Ms. The mentioned results seem to suggest that a large portion of students has general understanding of the subject and their knowledge is frequently wider than the one of practicing nurses (12).

However, in many other issues the knowledge of students is relatively scarce. Only one in four of the polled knows that independent prescribing will be a right, and not a duty, of nurses and midwives. Almost half the students did not know either that the regulations which empower N\&Ms to supplementary prescribing had already entered into force at the time when the study was conducted. When it comes to such basic information, a higher percentage of correct answers could be expected. On the other hand, $1^{\text {st }}$ year students cannot be expected to have detailed expertise in the principles of prescribing. Therefore, the respondents' scarce knowledge comes as no surprise when it comes to questions about placing the rates of patient's share in financing or the possibility of "discount" prescribing for those who enjoy special entitlements.

In the Polish scientific literature, a few academic publications have been found on the knowledge of students on N\&Ms' powers to independent prescribing and supplementary prescribing (7, 1314). Whereas in the Polish Medical Bibliography base (search descriptor: PRESCRIPTIONS NURSING; search's date: 1997-2017) two works have been found on the topic of nurse prescribing $(15,16)$

The results of the authors' study may be directly compared to studies conducted in 2015 in a group of students of different fields (13). In that study, a group of 535 students of the following fields: medicine, nursing, midwifery and public health, was asked questions on the scope of powers of N\&Ms. The broadest knowledge was demonstrated by nursing students and the poorest - by medicine students. When it comes to overall results, 39\% of the respondents knew in which act the issues in question were regulated, 29\% knew when new N\&Ms' powers would enter into force, and $30 \%$ knew where the list of medicines which N\&Ms may independently prescribe could be found. Those results are similar to the ones obtained in this study.

Whereas in a work of Zarzeka et al. (14) nursing students of different years were asked about N\&Ms powers. Within a certain scope, the results obtained were more satisfactory than in this study:
$69 \%$ of the respondents knew which legal act had introduced the powers, and $75 \%$ knew that the new competencies in independent prescribing would be a right, rather than a duty, of N\&Ms. Answers to other questions were similar to the ones obtained in this study: 29\% knew which groups of N\&Ms had been entitled to supplementary prescribing, 51\% knew the legal act which regulated the list of active substances allowed in medicines independently prescribed by N\&Ms.

In the international academic literature many publications on nurse prescribing were found (1719). Works on students' knowledge in this regard constituted a small portion of them (20-22). It should also be noted that studies on the knowledge of nursing students about supplementary nurse prescribing rather aimed to assess pharmacological knowledge.

The issue of prescribing powers of N\&Ms was raised by Hay, Bradley, and Nolan in their work (17). The study was carried out in Great Britain, wherein 2003 nurses became entitled to supplementary prescribing of a determined range of medicines "according to clinical management plan", established by a doctor in consultation with a patient. In 6 focus groups, both physicians and nurses had superficial knowledge on this kind of competences. The majority of the polled only knew that a nurse would be entitled to independently modify a medicine dosage. Only one person answered entirely correctly. This example illustrates that low awareness of the introduced changes, also amongst those most concerned, is not an isolated phenomenon.

The prescribing competencies of nurses is also a relevant topic in Spain. The knowledge on this area of Master's degree students, among others, was examined. $73 \%$ of the respondents claimed to know about legal changes in this regard. Nevertheless, 95\% of them admitted to gaps in such knowledge (20).

Whitechain et al. (21), on the other hand, were examining whether nursing students were able to identify errors in prescriptions. The respondents found it problematic. With five prescriptions containing errors, only $7 \%$ of the respondents were able to identify all five of them. $13 \%$ recognized four errors, $22 \%$ three errors, $27 \%$ only two errors, and $20 \%$ only one error.

Last but not least, the knowledge of students in the moment of graduation will depend on content and the quality of the pharmacology training, which they get during their academic education. Lim \& Honey (5) suggests, that "integrated approach" in pharmacology teaching, which includes e.g. ele- 
ments of law and ethics or communication skills was giving better results that education focused specifically on the pharmacology issues.

\section{Limitations}

This work is not free from certain limitations. Although an invitation to conduct the study was addressed to all Universities and State Higher Occupational Schools which offer education in nursing and midwifery, some centers did not undertake cooperation. Furthermore, some other schools which offer education in nursing and midwifery, in particular private universities, were not covered by the study. Nonetheless, group selection and the sample examined lead to the conclusion that the study is representative within a group of $1^{\text {st }}$ year students of Bachelor's studies in nursing and midwifery who undergo education in state higher schools and universities.

\section{CONCLUSIONS}

The knowledge of students of nursing and midwifery on the issue of N\&Ms' powers to independent and supplementary prescribing is quite superficial. It is comparable to the knowledge of students of different medical fields, including higher years students.

The study's results constitute a thorough diagnosis of the current knowledge of nursing and midwifery students on N\&Ms' advanced professional competencies. While improving the curriculum of these fields, it is necessary to correctly determine education standards and to focus on their implementation tools, so that those concerned could acquire desired competencies during studies.

\section{Acknowledgments}

We thank to our colleges from all of the involved in the research institutions, particularly to: Beata Jankowska-Polańska, Mariola Czajowska, Lesław Niebrój, Sonia Grychtoł, Małgorzata Kaczmarczyk, Małgorzata Andryszczyk, Ewa Krajewska, Teresa Gola, Justyna Paszkiewicz, Hanna Rolka, Monika Łabuzek, Alicja Franek, Ewa Roggenbuck, Lucyna Sochocka, Krystyna Kowalczuk, Katarzyna Juszczak, Maria Zięba, Halina Kalandyk, Renata Rabiasz, Hubert Słodziński, Mariola Głowacka, Małgorzata Lewandowska, Monika Binkowska-Bury, Małgorzata Starczewska, Urszula CisońApanasewicz, Łukasz Pietrzyk and Paula Drężek. Without their help and cooperation, performing the research would not be possible.
We would like to thank also to the Ministry of Health, particularly to Beata Cholewka - Director of the Department of Nursing and Midwifery for providing us with useful information.

\section{REFERENCES}

1. Ustawa z dnia 22 lipca 2014 r. o zmianie ustawy o zawodach pielęgniarki i położnej oraz niektórych innych ustaw.

2. Rozporządzenie Ministra Zdrowia z dnia 20 października 2015 r. w sprawie wykazu substancji czynnych zawartych w lekach, wykazu środków spożywczych specjalnego przeznaczenia żywieniowego, wykazu wyrobów medycznych i wykazu badań diagnostycznych.

3. Ustawa z dnia 27 sierpnia 2004 r. o świadczeniach opieki zdrowotnej finansowanych ze środków publicznych.

4. Rozporządzenie Ministra Zdrowia z dnia 28 października 2015 r. w sprawie recept wystawianych przez pielęgniarki i położne.

5. Lim A.G., Honey M.: Nurse Educ. Pract. 6, 163 (2006).

6. Romero-Collado A., Raurell-Torreda M., Zabaleta-Del-Olmo E., Rascon-Hernan C.,

7. Homs-Romero E.: Nurs. Health Sci. 19, 373 (2017).

8. Zarzeka A., Iwanow L., Pietruszewska K., Mazur M., Gorzkiewicz A. et al. Zdr. Publ. 7, 107 (2017).

9. Panczyk M., Zarzeka A., Iwanow L., Belowska J., Gotlib J., Pielęg XXI w. 54, 27 (2016).

10. Jankowski K., Zajenkowski M.: In Psychometrics - basic problems. Fronczyk K. (Ed.), pp. 84-110, Vizja Press \& IT, Warszawa 2009.

11. Tarrant M., Ware J., Mohammed A.M.: BMC Med. Educ. 9, 40 (2009)

12. Informacja Komisji Bioetycznej Warszawskiego Uniwersytetu Medycznego https://komisjabioetyczna.wum.edu.pl/content/szczeg\%C3\%B 3\% C5\%82owe-informacje-oraz-wzory-dokument\%C3\%B3w (date of access: 2017-07-19).

13. Zarzeka A., Panczyk M., Żmuda-Trzebiatowska H., Belowska J., Samoliński Ł. et al. Acta Pol. Pharm. 74, 1031 (2017)

14. Gotlib J., Zarzeka A., Panczyk M., Leszczyński P., Iwanow L. et al.: J. Public Health Nurs Med. Res. 2, 19, (2016)

15. Zarzeka A., Handzel S, Panczyk M., Belowska J., Gotlib J. in Romaniuk P., Grochowska-Niedworok E. (Ed.), pp. 147-159, Health for Public, Public for Health. Heath systems in V4 countries. Tygiel, Lublin 2016. 
16. Banaś I.: in Dominiak I., Gaworska-Krzemińska A., Kilańska D. (Ed.), Ordynowanie leków i wypisywanie recept: przewodnik dla pielęgniarek i położnych, pp. 236-241, Edumetriq Akademia Ochrony Zdrowia, Sopot 2016.

17. Bartosiewicz A., Binkowska-Bury M., Januszewicz P., Prz. Med. Uniw. Rzesz. Inst. Leków 13, 290 (2015).

18. Hey A., Bradley E., Nolan P.: Nurs. Stand. 41, 33 (2004).

19. Kroezen M., Francke A.N., Groenewegen P., van Dijk L.: Int. J. Nurs. Stud. 49, 1002 (2012).
20. Gielen, S.C., Dekker J., Francke A.L., Mistiaen P., Kroezen M.: Int. J. Nurs. Stud. 51, 1048 (2014).

21. Cabrera-Jaime S., Estrada-Masllorens J.M., Fernández-Ortega P.: Enferm. Clin. 21, 84 (2011).

22. Whitehair L., Provost S., Hurley J.: Nurse Educ. Today 34, 225 (2014).

23. McMullan M., Jones R., Lea S.: J. Adv. Nurs. 66 891-899 (2010).

Received: 16. 10. 2017 